DOI:10.22337/2587-9618-2019-15-4-58-65

\title{
OPTIMIZATION OF SIMPLY SUPPORTED CASTELLATED I-BEAMS LOADED BY A UNIFORMLY DISTRIBUTED LOAD
}

\author{
Oleg S. Goryachevskiy \\ National Research Moscow State University of Civil Engineering, Moscow, RUSSIA \\ Scientific Research Center «StaDyO», Moscow, RUSSIA \\ Russian University of Transport (MIIT), Moscow, RUSSIA
}

\begin{abstract}
The paper discusses the problem of optimizing the geometric parameters of simply supported I-beams in order to maximize their load carrying capacity. Numerical simulation of various types of failure of castellated Ibeams with ideal elastic-plastic steel is carried out. The stability of the wall, the strength of the welds and flanges, depending on the geometric parameters investigated. Using the coordinate descent method, the optimization problem is solved for nine design schemes with respect to the section height and the weld length. It was revealed that in short beams the section height should be less and the weld length longer, in contrast to long beams.
\end{abstract}

Keywords: castellated I-beam, numerical simulation, optimization, ideal elastic-plastic material

\section{ОПТИМИЗАЦИЯ СВОБОДНО ОПЕРТЫХ РАЗВИТЫХ ДВУТАВРОВ, НАГРУЖЕННЫХ РАВНОМЕРНО РАСПРЕДЕЛЕННОЙ НАГРУЗКОЙ}

\author{
О.С. Горячевский \\ Национальный исследовательский Московский государственный строительный университет, \\ г. Москва, РОССИЯ \\ Научно-исследовательский центр СтаДиО, г. Москва, РОССИЯ \\ Российский университет транспорта (МИИТ), г. Москва, РОССИЯ
}

\begin{abstract}
Аннотация: В статье рассматривается проблема оптимизации геометрических параметров развитых двутавров с перфорированной стенкой с целью максимизации их несущей способности. Проведено численное моделирование различных типов разрушения развитых двутавров в идеальной упругопластической постановке. Исследована устойчивость стенки, прочность швов и полок в зависимости от геометрических параметров. Используя метод покоординатного спуска, решена проблема оптимизации для девяти расчетных схем относительно двух параметров: высоты сечения и длины сварного шва. Выявлено, что в коротких балках высота сечения должна быть меньше, а длина шва больше, чем в длинных балках.
\end{abstract}

Ключевые слова: развитые двутавры, численное моделирование, оптимизация, идеальный упругопластический материал

\section{INTRODUCTION}

Existing analytical methods for calculating strength, rigidity and stability of castellated Ibeams give a very approximate result [1-2]. These methods bad take in account a complexity of the geometric shape of the castellated Ibeams and plastic deformation steel in angles of holes. These factors can be taken account with sufficient accuracy only by experiment and numerical methods. Of practical interest is the question of choosing such geometric parameters zigzag cutting I-beam that will provide maximum load carrying capacity of castellated Ibeam. But experiment methods are too expensive and time-consuming for their application in full optimization problem. 
a)

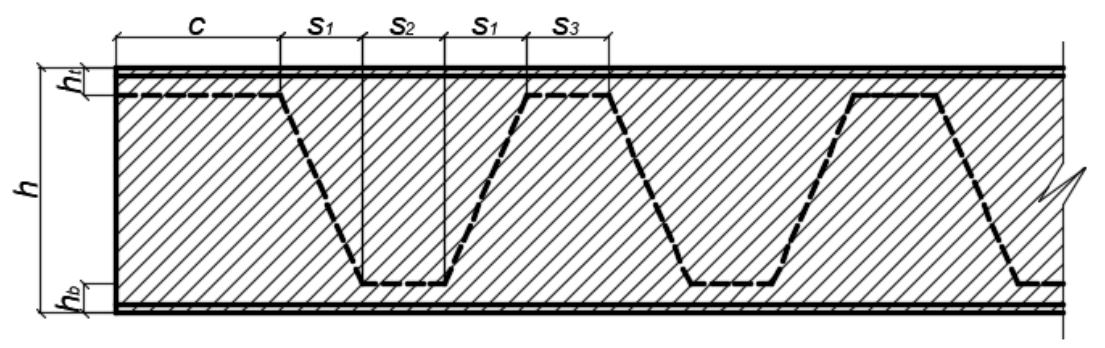

b)

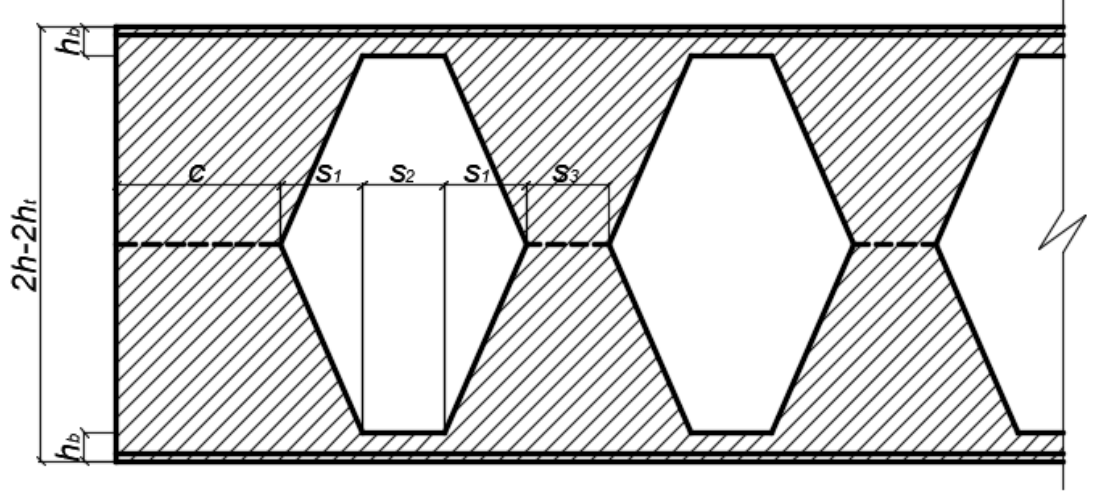

c)

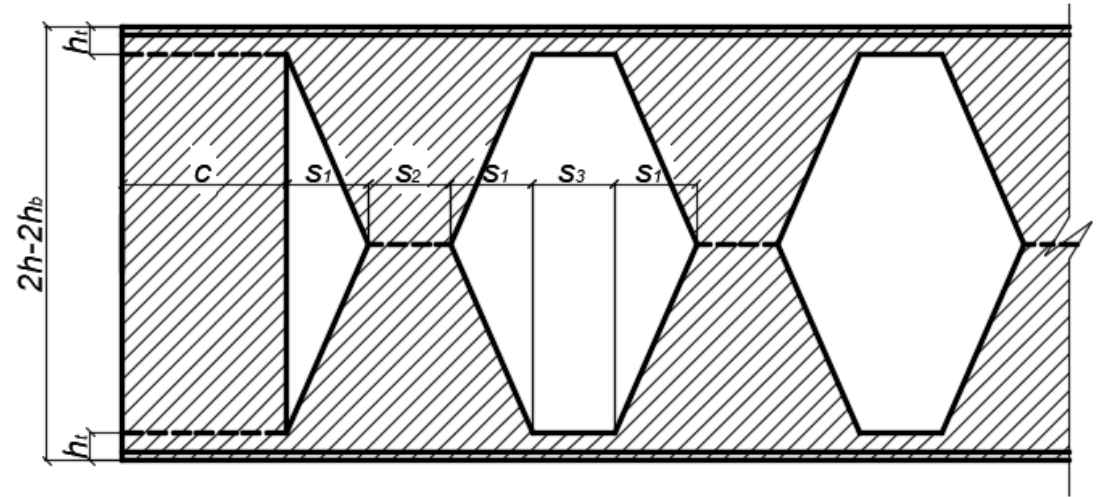

Figure 1. Scheme method for cutting (a) and subsequent welding of halves $(b, c)$ of the original I-beam.

In this paper, to solve the nonlinear optimization problem, numerical methods are used. Stressstrain state and buckling is calculated by the finite element method. Using FEM analysis results, the ultimate load on the castellated I-beam is calculated according to several criteria (more about the criteria will be further in the text). To search the optimal geometric parameters, the coordinate descent method is used.

ANSYS Mechanical is used to solve the problem. APDL macros allow automated load carrying capacity calculation and use powerful capabilities of ANSYS in the finite element analysis [3].

There are several methods for cutting and subsequent welding of halves of the I-beam. Differ- ent methods give different relationship between geometric parameter. The paper adopts the method illustrated in the Figure 1.

The article discusses the optimization of the load carrying capacity of the castellated I-beam composed of the lower halves of the original Ibeams (Figure 1a). In order for the holes to be the same in both versions of the castellated Ibeam (Figure 1b, 1c)

$$
s_{2}=s_{3}
$$

Radius of fillet in the corners due to cutting $r=1 \mathrm{~cm}$.

The design scheme: beam supported at its ends and loaded by a uniformly distributed load Q. 


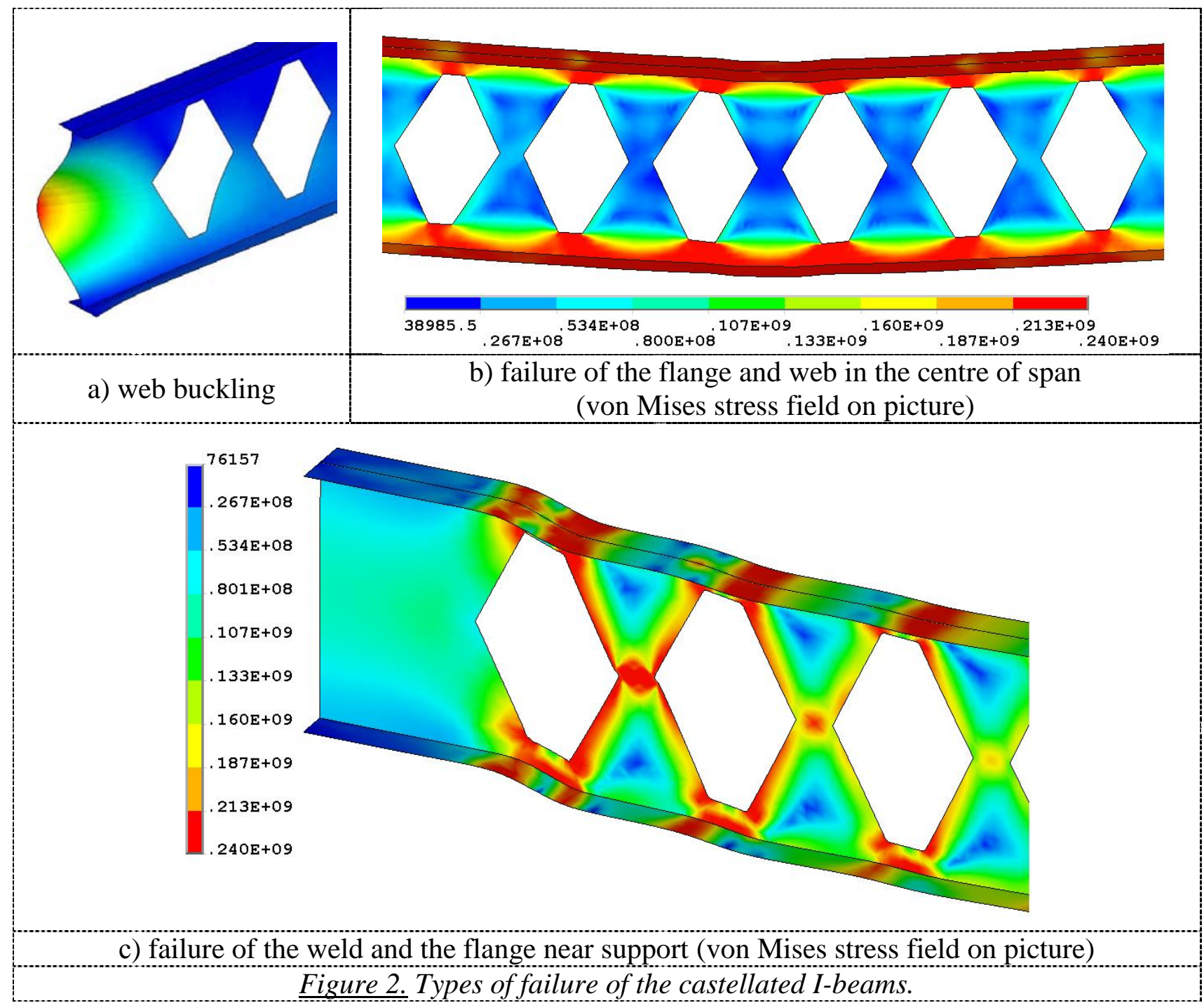

The material model (steel): ideal elastic-plastic (stress-strain curve with elastic modulus $E=206 \mathrm{GPa}$, yield strength $\sigma_{y}=240 \mathrm{MPa}$, Poisson's ratio $v=0.3$ ).

Geometric parameters of the original I-beams are taken according to GOST 8239-89 [4].

\section{LOAD CARRYING CAPACITY PARAM- ETERS}

There are 4 types of failure of the castellated Ibeam supported at its ends and loaded by a uniformly distributed load:

1. Web buckling (Figure 2a).

2. Failure of the flange and web in the field of angles in the centre of span (Figure 2b).
3. Failure of the flange and web in the field of angles near support (Figure 2c).

4. Failure of the weld (Figure 2c).

For all types of failure, three parameters can be introduced:

1. $F_{b}=F_{c r} / 1.5$, where $F_{c r}$ - the first critical load, 1.5 - safety factor [1].

2. $F_{f}$ - load at which plastic strain completely fills the section of the flange.

3. $F_{w}$ - load at which plastic strain completely fills the weld between two holes.

To automatic calculate the $F_{b}$, a buckling analysis (by the Block Lanczos method, linear material model) was first performed. Then the first critical load $F_{c r}$ devided by safety factor 1.5 , due to the possible eccentricity of the load and the initial imperfections of the castellated I-beam. 
The top flange was fixed against possible lateral movement and rotation around the longitudinal axis, thereby simulating the mounting of the castellated I-beam to overlying structures. The top flange boundary condition us used only in buckling analysis, since it strongly affects the forms of buckling.

To automatic calculate the $F_{f}$ and $F_{w}$, a linear static calculation (linear material model) was initially performed to determine the load $F_{p}$ at which plastic appears in the castellated I-beam flange. Then a load equal $1.2 F_{p}$ was applied and the static calculation was performed with a nonlinear material with a load step of 0.01 . The load $1.2 F_{p}$ is likely to lead to the failure of the Ibeam, because according to analytical decisions, $\approx 1.18 F_{p}$ is enough. Then, in the Postprocessor, a special algorithm at each load step checks for plastic strain in the nodes of the flange and nodes of the weld. If at some load step in a some section of the flange or in the weld in all nodes there are plastic strain, then this load step is recognized as the moment of failure. So,

$$
\begin{aligned}
F_{f} & =1.2 F_{p}[i / 100+(i-1) / 100] / 2, \\
F_{w} & =1.2 F_{w}[j / 100+(j-1) / 100] / 2,
\end{aligned}
$$

where $i$ - load step is recognized as the moment of failure flange, $j$ - load step is recognized as the moment of failure weld.

Ideal elastoplastic material behaves unphysically in the support zone. If fix the beam pointwise on the edge, then near the fastening large plastic strain will quickly develop and the solution will fall apart. Therefore, in a nonlinear analysis at the edges of the beam, all nodes in the section were fixed in the direction of deflection. This avoids problems with the boundary effects.

\section{FINITE ELEMENT MODELS}

Geometric and finite element model are created automatically using developed APDL macros [3]. In the area between the last holes, and also above them and central holes, the mesh is more detailed. Failure occurs in these areas. Only the top flange for searching for plastic strain is considered, as it does not have boundary effect of supports (Figure 3).

The weld does not differ geometrically and in properties from the steel of original I-beam.

Elements type - Shell 181. In the buckling analysis, to combat non-physical buckling forms, full integration in the wall elements was used. Also, a coarser grid was used in the linear and buckling analyses.

a)

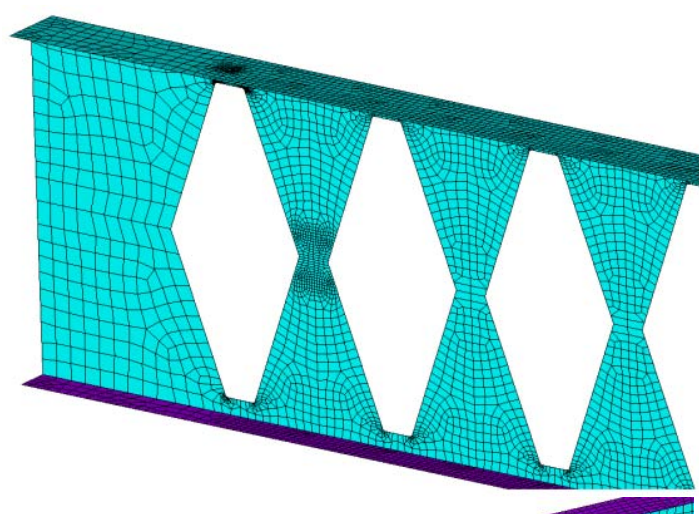

b)

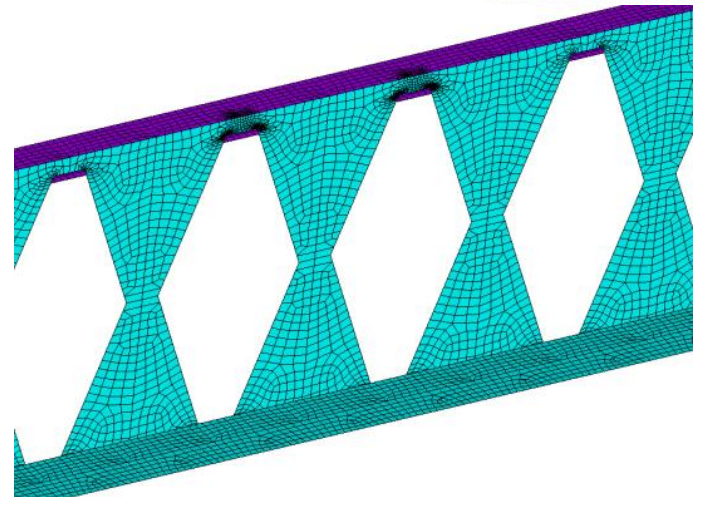

Figure 3. Fragments of the finite element model.

Number of elements: 15-40 thousands depending on the length of the beam and the number of holes.

\section{DEPENDENCE OF $F_{b}, F_{f}$ AND $F_{w}$ ON GEOMETRUC PARAMETERS}

The important points to make about $F_{w}$ and $F_{f}$ calculations:

- if $F_{f}<F_{w}$ (much), then $F_{w}$ cannot be calculated correctly. The fact is that with the destruction of the flange of the castellated I- 
beam, the entire structure suffers a collapse - a sharp increase in deflections and plastic strain. In such conditions, the solution loses stability and cannot give correct results;

- if weld length $s_{2}$ is large enough, then the weld failure does not occur under load $1.2 F_{p}$. In this case, $F_{w}$ is not calculated.

- if $F_{w}$ and $F_{f}$ changed less than $1 \%$, when changing the argument, then curve $F_{w}$ and $F_{f}$ may contain some fluctuations, because load step is also $1 \%$.

The geometric parameters of cutting significantly affect both the magnitude of the $F_{b}, F_{f}$ and $F_{w}$ and the types of failure. For example, large values of $c$ and $h_{b}$ increase stability $\left(F_{b}\right)$, small values $s_{2}$ decreases weld strength $\left(F_{w}\right)$. However, many other dependencies are not obvious and require preliminary study (figure 4).

Figure $4 \mathrm{a}$ shows the dependence of $F_{b}, F_{f}$ and $F_{w}$ on $c . F_{b}$ is obviously increasing, $F_{f}$ increasing as the failure of the flange at the support is moving away from the support, $F_{w}$ decreases as reduced weld length $s_{2}$ ( $s_{1}$ is fixed). The reasonable change $c$ does not reveal the presence of extrema.

The number of holes $N$ affects the weld length $s_{2}$ (if $s_{1}$ is fixed), so $F_{w}$ decreases (figure $4 \mathrm{~b}$ ). Stability almost independent of hole count $N$. Flange strength decreases after weld failure two holes merge into one and the span of the flange increases.

\section{STATEMENT OF OPTIMIZATION PROBLEM OF THE CASTELLATED I-BEAM}

The problem of maximizing the load carrying capacity can be defined as follow [5-6]:

$$
F=\min \left(F_{b}, F_{f}, F_{w}\right) \rightarrow \max
$$

Objective function $F$ depends on the geometric parameters, type of load and support condition.

For the selected cutting method (Figure 1), the uniformly distributed load and supported at its ends:

$$
F=F\left(I, L, c, r, N, s_{1}, s_{2}=s_{3}, h_{b}=h_{t}\right),
$$

where $L$ - length of beam, $I$ - number of profile, which defines a number of geometric parameters of section, $r$ - radius of fillet in the corners due to cutting.

Parameter $s_{1}$ is not independent:

$$
s_{1}=\left(L-2 c-(2 N-1) s_{2}\right) / 2 N .
$$

Parameters $I$ and $L$ do not change during of one optimization problem. $r=10 \mathrm{~mm}$ for all schemes. In the article, we will determine $c$ and $N$ ourselves, and we will optimize only for two parameters $s_{2}$ and $h_{b}$. Thus, for each design scheme:

$$
F=F\left(s_{2}, h_{b}\right)
$$

Only geometrically inequality constraints:

$$
\begin{gathered}
0<s_{2}<(L-2 c) /(2 N-1), \\
t<h_{b}<h / 2,
\end{gathered}
$$

where $t$ - thickness of flange, $h$ - height of original I-beam.

From a technical point of view, we can narrow the conditions without risking losing the optimal point:

$$
\begin{gathered}
20 m m \leq s_{2} \leq(L-2 c) /(2 N-1)-10 m m, \\
2 t \leq h_{b} \leq 2 h / 5
\end{gathered}
$$

Computation the objective function using the finite element method has some problems. Nonlinear material properties and a difference in the mesh at different points introduce a small noise into the objective function. The presence of noise does not allow the use of derivative-based optimization methods and impairs convergence [7-8]. 




a) Dependence of $F_{b}, F_{f}$ and $F_{w}$ on the $c$ $c \in[50 ; 400] \mathrm{mm}$, step $10 \mathrm{~mm}$

$I 30, L=6 m, N=16, s_{1}=100 \mathrm{~mm}, h_{b}=50 \mathrm{~mm}$



c) Dependence of $F_{b}, F_{f}$ on the $h_{b}$ $h_{b} \in[20 ; 200] \mathrm{mm}$, step $10 \mathrm{~mm}$

$I 50, L=12 \mathrm{~m}, N=24, c=400 \mathrm{~mm}, s_{2}=85.1 \mathrm{~mm}$

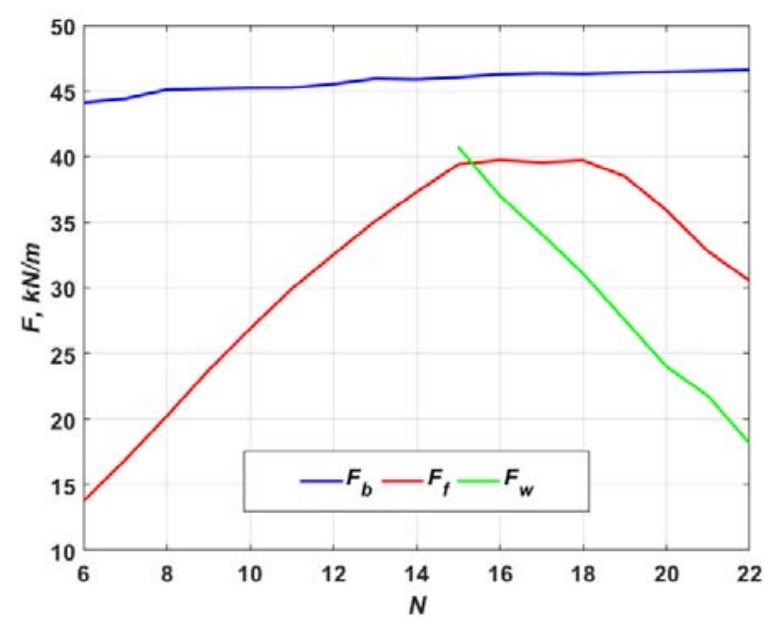

b) Dependence of $F_{b}, F_{f}$ and $F_{w}$ on the $N$ $N \in[6 ; 22]$, step $1 \mathrm{pc}$

$I 30, L=6 \mathrm{~m}, c=300 \mathrm{~mm}, s_{1}=100 \mathrm{~mm}, h_{b}=60 \mathrm{~mm}$

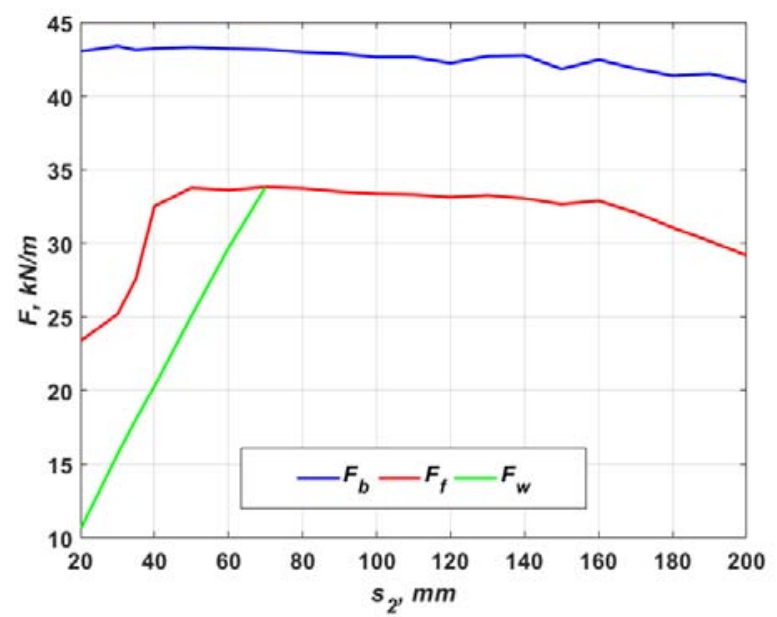

d) Dependence of $F_{b}, F_{f}$ and $F_{w}$ on the $s_{2}$ $s_{2} \in[20 ; 200] \mathrm{mm}$, step $10 \mathrm{~mm}$

I50, $L=12 \mathrm{~m}, N=24, c=400 \mathrm{~mm}, h_{b}=80 \mathrm{~mm}$

Figure 4. Dependence of $F_{b}, F_{f}$ and $F_{w}$ for some configuration of castellated I-beam.

\section{OPTIMIZATION RESULTS}

To search the optimal point $\left(s_{2}^{*}, h_{b}^{*}\right)$, the coordinate descent method was used. At each iteration, the golden-section search was used as the linear search method. The optimal point was calculated with sufficient accuracy after two iterations of the coordinate descent method.

Initial point:

$$
\left(s_{2}^{0}, h_{b}^{0}\right)=\left(\frac{s_{2}^{\min }+s_{2}^{\min }}{2} ; \frac{h_{b}^{\min }+h_{b}^{\min }}{2}\right) .
$$

Tolerance of golden-section search

$$
\Delta s_{2} \leq 2.5 \mathrm{~mm} ; \quad \Delta h_{b} \leq 2.5 \mathrm{~mm} .
$$

The optimization results are presented in Table 1 and Figure 6.

An important non-dimensional parameter of castellated I-beams - height increase ratio (Table 2). 
Table 1. Optimization results.

\begin{tabular}{|c|c|c|c|c|c|c|c|c|c|c|c|c|}
\hline \multirow{2}{*}{ No. } & \multirow[t]{2}{*}{ I } & \multirow{2}{*}{$\mathrm{L}, \mathrm{m}$} & \multirow{2}{*}{$\mathrm{c}, \mathrm{mm}$} & \multirow{2}{*}{$\mathrm{N}$} & \multicolumn{3}{|c|}{$\mathrm{s} 2, \mathrm{~mm}$} & \multicolumn{3}{|c|}{$\mathrm{hb}, \mathrm{mm}$} & \multicolumn{2}{|c|}{$\mathrm{F}, \mathrm{kN}$} \\
\hline & & & & & $\min$ & $\max$ & opt & $\min$ & $\max$ & opt & $\min$ & $\max$ \\
\hline 1 & \multirow{3}{*}{30} & 4 & 300 & 10 & 20.0 & 7 & 99.6 & 20.4 & 120.0 & 77.5 & 59.73 & 70.70 \\
\hline 2 & & 6 & 300 & 16 & 20.0 & 164.2 & 79.1 & 20.4 & 120.0 & 67.4 & 28.61 & 39.33 \\
\hline 3 & & 8 & 300 & 20 & 20.0 & 179.7 & 93.3 & 4 & 120.0 & 57.4 & 19.10 & 22.53 \\
\hline 4 & \multirow{3}{*}{40} & 5 & 350 & 12 & 20.0 & 177.0 & 107.2 & 26.0 & 160.0 & 117.2 & 78.04 & 98.90 \\
\hline 5 & & 8 & 350 & 16 & 20.0 & 225.5 & 94.9 & 26.0 & 160.0 & 80.9 & 32.57 & 44.96 \\
\hline 6 & & 10 & 350 & 20 & 20.0 & 228.5 & 80.0 & 26.0 & 160.0 & 78.1 & 26.25 & 29.19 \\
\hline 7 & \multirow{3}{*}{50} & 6 & 400 & 12 & 20.0 & 216.1 & 122.7 & 30.4 & 200.0 & 156.4 & 89.59 & 115.83 \\
\hline 8 & & 9 & 400 & 20 & 20.0 & 200.3 & 92.7 & 30.4 & 200.0 & 99.9 & 46.35 & 59.11 \\
\hline 9 & & 12 & 400 & 20 & 20.0 & 277.2 & 89.6 & 30.4 & 200.0 & 96.3 & 19.74 & 33.78 \\
\hline
\end{tabular}

Table 2. Height increase ratio.

\begin{tabular}{|c|c|c|c|c|c|c|c|c|c|}
\hline No. & 1 & 2 & 3 & 4 & 5 & 6 & 7 & 8 & 9 \\
\hline$k$ & 1.48 & 1.55 & 1.61 & 1.41 & 1.60 & 1.61 & 1.37 & 1.60 & 1.61 \\
\hline
\end{tabular}

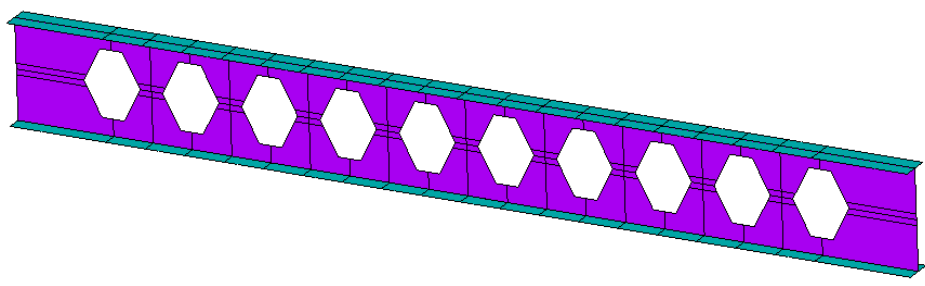

a) $I 30, L=4 m, c=300 \mathrm{~mm}, N=10$



b) $I 40, L=10 \mathrm{~m}, c=350 \mathrm{~mm}, \mathrm{~N}=20$

Figure 5. Several optimized castellated I-beams: No. 1 (a) and No. 6 (b) from Table 1.

$$
k=2\left(h-h_{b}\right) / h=2\left(1-h_{b} / h\right) .
$$

\section{CONCLUSIONS}

Castellated I-beam load carrying capacity has maximum for many design schemes. However, for some geometric parameters, not all schemes have extrema. Nevertheless, the task of increasing the carrying capacity remains relevant.
Section height and weld length always have a maximum point, therefore, in this work, the problem of optimizing these parameters was solved.

Based on the 9 considered design schemes (Table 1), some conclusions can be drawn:

- the optimal height increase ratio of castellated I-beams increases with increasing span (Table 2)

- the relative length of the weld decreases with increasing span.

The first conclusion is explained by the fact that in short beams, destruction occurs in the zone of 
supports. Wall height is a determining factor in its stability. However, stability can be ensured by installing stiffeners. It can be expected that when using stiffeners, the optimal solution will change. In long beams, destruction occurs in the middle of the span from the action of a bending moment. In such type of failure, an increase in the inertia moment by increasing the section height gives the greatest increase in the carrying capacity.

The second conclusion is also related to the type of failure. Welds between end holes have the highest stresses. Therefore, the cause of the loss of loadcarrying ability may be the failure of the weld. Increasing the weld length solves this problem.

\section{REFERENCES}

1. SP 16.13330.2011 Stal'nye konstrukcii [Steel constructions]. Moscow, Minregion Rossii, 2011.

2. Pritykin A.I. Razrabotka metodov rascheta i konstruktivnyh reshenij balok s odnoryadnoj i dvuryadnoj perforaciej stenki [Development of calculation methods and design solutions for beams with single and double row wall perforations]. Diss. na soiskanie uchenoj stepeni d.t.n. Kaliningrad: KGTU, 2011, 331 pages.

3. ANSYS Mechanical 19.2 Tutorials. Canonsburg, 2019.

4. GOST 8239-89 Hot-rolled steel flange beams. Rolling products. Moscow, IPK Izdatel'stvo standartov, 2003.

5. Haug E.J., Arora J.S. Prikladnoe optimal'noe proektirovanie: Mehanicheskie sistemy i konstrukcii [Applied optimal design: Mechanical and structural systems]. Moscow, Mir, 1983, 478 pages

6. Malkov V.I., Ugodchikov A.G. Optimizaciya uprugih system [Optimization of elastic systems]. Moscow, Nauka, 1981, 288 pages.

7. Kochenderfer M.J., Wheeler T.A. Algorithm for optimization. Cambridge, Massachusetts, The MIT Press, 2019, 500 pages.

8. Vasil'ev F.P. Metody optimizacii [Optimization methods]. Moscow, Izdatel'stvo "Faktorial Press", 2002, 824 pages.

\section{СПИСОК ЛИТЕРАТУРЫ}

1. СП 16.13330.2011 Стальные конструкции. - М.: Минрегион России, 2011.

2. Притыкин А.И. Разработка методов расчета и конструктивных решений балок с однорядной и двурядной перфорацией стенки. Диссертация на соискание ученой степени доктора технических наук по специальности 05.23.01 - «Строительные конструкции, здания и сооружения». Калининград: КГТУ, 2011. - 331 с.

3. ANSYS Mechanical 19.2 Tutorials. Canonsburg, 2019.

4. ГОСТ 8239-89 Двутавры стальные горячекатаные. Сортамент. М.: ИПК Издательство стандартов, 2003.

5. Хог Э., Арора Я. Прикладное оптимальное проектирование: Механические системы и конструкции. - М.: Мир, 1983. - 478 с.

6. Малков В.И., Угодчиков А.Г. Оптимизация упругих систем. - М.: 1981. - 288 с.

7. Kochenderfer M.J., Wheeler T.A. Algorithm for optimization. Cambridge, Massachusetts, The MIT Press, 2019, 500 pages.

8. Васильев Ф.П. Методы оптимизации. М.: Издательство «Факториал Пресс», 2002. $-824 \mathrm{c}$.

Oleg G. Goryachevskiy, Lecturer at the Department of Applied Mathematics, National Research Moscow State University of Civil Engineering, Senior Engineer of Scientific Research Center "StaDyO", Director of Center of Computer Simulation, Russian University of Transport (MIIT); office 810, 18, 3ya Ulitsa Yamskogo Polya, Moscow, 125040, Russia; phone +7 (499) 706-88-10,

E-mail: osgoryachevskij@mail.ru.

Горячевский Олег Сергеевич, преподаватель и аспирант кафедры прикладной математики Национального исследовательского Московского строительного университета, ведущий инженер расчетчик ЗАО «Научноисследовательский центр СтаДиО» (ЗАО НИЦ «СтаДиО»), директор Центра компьютерного моделирования (ЦКМ) Российского университета транспорта; 125040, Россия, г. Москва, ул. 3-я Ямского Поля, д.18, 8 этаж, офис 810, тел. +7 (495) 706-88-10;

E-mail: osgoryachevskij@mail.ru. 